\title{
Case of Encephalitis due to Herpes Simplex*
}

\author{
W. BLACKWOOD, F.R.C.P.ED., F.R.C.S.ED., F.C.PATH. ; J. A. DUDGEON, M.C., M.D., F.C.PATH. \\ G. H. NEWNS, M.D., F.R.C.P. ; B. M. PHILLIPS, M.B., M.R.C.P.
}

Brit. med. F., 1966, 1, 1519-1521

Localized, predominantly temporal, asymmetrical necrotizing encephalitis is a well-recognized morbid-anatomical entity, though published' accounts of cases in Great Britain are few. Often the aetiology is not established, so that all cases where the infective agent has been isolated or proved should be reported (Adams et al., 1961). Herpes simplex virus was isolated by Smith et al. (1941) from the brain of a child who died after acute encephalitis, and since then numerous cases have been published. Clinically the condition may present as a space-occupying lesion simulating an abscess or a neoplasm (Drachman and Adams, 1962 ; MacCallum et al., 1964 ; Pierce et al., 1964), and it is in this type of case that virological studies may be of great value in respect to further management. The true incidence of necrotizing encephalitis due to the herpes simplex virus is unknown, but in all probability it is much higher than the literature would suggest. A recent series of cases of infection of the central nervous system by that virus, collected over a period of three years, totalled 52 (Leider et al., 1965), but these included examples of aseptic meningitis, disseminated herpes simplex infection of infancy, and the encephalitic form.

\section{Case Report}

A 13-year-old schoolgirl was admitted to hospital on 11' September 1963 after a focal seizure. There was no relevant past illness, and the family history contained nothing of note.

The first symptoms dated back to two months before her admission, when the parents noted a tendency to mispronounce words and an occasional difficulty with reading. During the early part of the illness the child became "preoccupied with religious thoughts." Three weeks before her admission morning headaches associated with nausea and vomiting developed and became progressively more severe. Two weeks after the onset of headaches depression, with morbid utterances, became a feature, and the child experienced brief episodes in which her surroundings became distorted.

On 3 September an episode of tingling in the right hand occurred associated with slurred speech and drooping of the right side of the face. Two days later the child was admitted to the Hospital for Sick Children, Great Ormond Street, under the care of Dr. G. H. Newns, when physical examination revealed bilateral papilloedema, a mild right facial weakness, but no long tract signs in the limbs. A full general physical examination was also negative. Investigations at this stage showed that the full blood count, including the erythrocyte sedimentation rate, was normal; and $x$-ray pictures of the chest and skull were within normal limits.

An electroencephalogram recorded on 12 September was reported by Dr. G. Pampiglione as showing pronounced generalized abnormality, maximal about the right fronto-Sylvian region but also involving the posterior half of the hemisphere, especially on the right side. A right carotid arteriogram and a pneumoencephalogram excluded a space-occupying lesion.

Examination of the lumbar-cerebrospinal-fluid on 16 September revealed a rise in the protein level to $150 \mathrm{mg} . / 100 \mathrm{ml}$. and there were 30 lymphocytes per c.mm.

Over the course of the next few weeks the child continued to experience brief episodes in which her surroundings were distorted, and she vividly described macropsia and micropsia. Towards the

* From the Institutes of Neurology and Child Health, the National Hospital, Queen Square, and the Hospital for Sick Children, Great Ormond Street, London. end of this period a rapid deterioration of memory, vision, and speech occurred, so that by 11 October, when she was transferred to the National Hospital, Queen Square, under the care of Dr. M. Kremer (N.H. Hosp. No. A. 14240), a gross dysphasia and dysarthria prevented accurate assessment of her mental state. On examination of the cranial nerves at this stage the papilloedema was severe, with haemorrhages and exudates in both fundi. The pupils were large, gave a poor response to light, and to confrontation there was a left homonymous hemianopia. Bilateral pyramidal signs involving the face and limbs were present, more pronounced on the left. The reflexes were pathologically brisk in the upper limbs but present only on reinforcement in the legs, and both plantar responses were extensor. The only other abnormality noted in the limbs was a slight impairment of joint position sense.

Numerous haematological investigations were carried out, including liver-function studies and a Paul-Bunnell test, but no abnormality was discovered. Urine analysis for metachromatic material and abnormal amino-acids was negative.

A repeat lumbar puncture on 15 October revealed clear fluid at a pressure of $300 \mathrm{~mm}$. of C.S.F. The protein was $100 \mathrm{mg} . / 100 \mathrm{ml}$. and only 2 lymphocytes per c.mm. were seen. Culture for pyogenic organisms and tubercle bacilli were negative (Professor J. N. Cumings). The electroencephalogram was recorded during barbiturate-induced sleep on 17 October and during waking on 23 October; both records showed diffuse moderately high voltage, irregular slow activity at about $1 \mathrm{c}$./ sec. with predominance on the right side (Dr. W. A. Cobb).

During life a clinical diagnosis of Schilder's disease seemed the most probable explanation, and on the basis of this a course of A.C.T.H. was given without benefit, for she pursued a downhill course with increasing bulbar palsy, loss of reflexes, and drowsiness. Death occurred on 27 October, approximately three and a half months after the onset of her illness.

\section{Necropsy Findings}

The body was that of a well-developed, well-nourished girl. Apart from pulmonary congestion and oedema the abnormal findings were confined to the central nervous system. The skull, air sinuses, middle ears, dura', and venous sinuses appeared healthy.

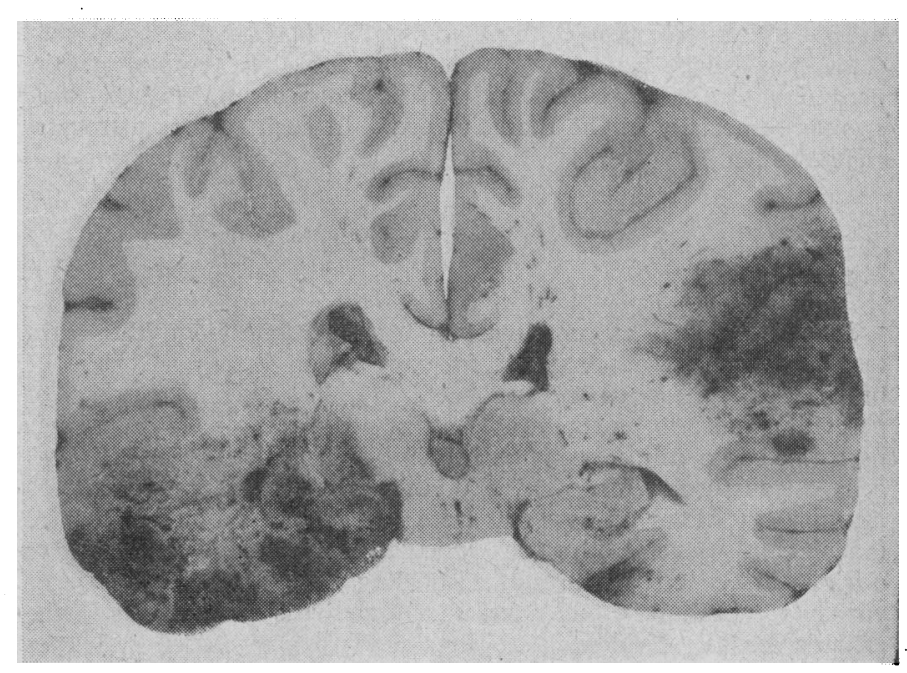

Coronal slice of brain at level of pineal seen frcra the front. Note tho haemorrhagic necrotic regions on both leit and right (left of picture). 
Both cerebral hemispheres were swollen. In many places, particularly in the right temporal lobe and occipital convexity, the surface of the brain was discoloured, consisting of a yellow and necroticlooking central area bordered by a broad zone of intense congestion well demarcated from the surrounding brain. On section the maximal involvement was seen to be in the cerebral cortex, with extension into the adjacent swollen white matter. The largest focus extended from the inferior region of the right insula forwards to involve all the temporal lobe, including the hippocampus, medially into the basal ganglia, and posteriorly tailing off towards the occipital pole. On the left side the superior half of the insula was involved, and this focus extended superiorly into the fronto-parietal region (see Fig.). Smaller foci were seen in the orbital surface of each frontal lobe, in the left cingulate and left hippocampal regions, in both cerebellar tonsils and, a very small one, in the posterior columns in the mid-thoracic cord.

\section{Microscopical Examination}

The foci in the cerebrum were essentially similar, consisting of a central zone of necrosis, with or without haemorrhage, and a peripheral zone, which, in the grey matter, consisted of regions where the nerve cells were dying or dead, and where the astrocytes were not obviously increased in number but their cytoplasm was increased in amount and their nuclei were often greatly swollen and pale. Microglia were present in these regions in the form of rod cells or compound granular corpuscles. Small dark nuclei, presumably oligodendroglia, were present in apparently normal numbers. The most striking feature, however, was the presence around the bloodvessels of small mononuclear cells and of large pale ovoid or elongated nuclei. In one place only a large rounded eosinophilic inclusion body bordered by a halo was visible in the nucleus of a cell which appeared to be a nerve cell. Sometimes the necrotic zone reached to the surface of the brain and sometimes did not. The subarachnoid space varied correspondingly in its complement of mononuclear cells and phagocytes. In places it also contained a considerable amount of eosinophilic amorphous material.

In the white matter the necrotic zone was again bordered by a zone in which perivascular monocytic cuffing and infiltration were a noticeable feature. Swollen-bodied astrocytes, of ten with swollen nuclei, were to be seen in the tissue, which appeared somewhat loosened in consistence.

Astrocytic fibre formation was not demonstrated in either white or grey matter. Within the necrotic zones there were sometimes haemorrhages, sometimes vessels with necrotic walls, sometimes vessels with healthy-looking walls, surrounded by compound granular corpuscles; all of which suggested that the haemorrhage and necrosis followed rather than preceded the inflammatory cellular reaction.

Inflammatory infiltration and minor tissue damage were visible at the periphery of the optic chiasm. In the pons and medulla there was a slight excess of mononuclear cells in the leptomeninges, and occasional perivascular foci of large and small mononuclear cells were present near the pia and under the ependyma. In the cerebellum the lesions were confined to the tonsils. In the spinal cord there was slight leptomeningeal infiltration. In places, at the periphery of the cord, occasional axons and myelin sheaths were swollen, especially in the thoracic cord. In such regions astrocytes were swollen.

\section{Virus Studies}

Material taken at post-mortem examination from the right temporal cortex was prepared for inoculation by emulsifying the brain tissue in virus culture medium containing 500 unis of penicillin and $500 \mu \mathrm{g}$. of streptomycin per $\mathrm{ml}$. This material was inoculated into cell cultures of primary-monkey kidney and RK-13 cells, a transformed line of rabbit-kidney cells; it was also inoculated into several litters of newborn mice and into a rabbit by corneal inoculation. Several days after inoculation cytopathic changes were obvious in the cell cultures, the suckling mice showed evidence of an acute encephalitis, and a keratoconjunctivitis was present in the rabbit's cornea. Evidence that these changes were caused by herpes simplex virus was established by microscopical examination of the cell cultures and the finding of intranuclear inclusions in the suckling mice. The virus isolated was neutralized by a specific herpes antiserum.

\section{Discussion}

In infants herpes simplex virus may involve the central nervous system as part of a fulminating illness, including widespread systemic lesions. Acute necrotizing encephalitis as in the case described here has been recognized with increasing frequency since its importance was stressed by Haymaker (1949), who recorded three cases confirmed by virological studies. This form is most prevalent in children and young adults, though cases have been observed in older age groups-for example, Drachman and Adams (1962) described the case of a patient aged 77. Most of the reported cases ended in deatr. within the first 18 days of the illness, though Pierce et al. (1964) and MacCallum et al. (1964) give accounts of patients recovering from the acute illness and being still alive a year later. In the series of 18 cases followed up by Leider et al. (1965) 14 of the patients were still alive after three years.

The clinical picture is often difficult to interpret, for many patients present with focal signs and raised intracranial pressure, as in the case reported above. Pierce et al. (1964) and MacCallum et al. (1964) each described two cases showing temporal-lobe masses with angiographic changes consistent with intracerebral tumours. A lymphocyte increase in the cerebrospinal fluid along with a rise in the protein may suggest an encephalitic process, though in many cases where the intracranial pressure is high the cerebrospinal fluid would not necessarily be examined. Angiographic findings are non-specific, as are areas of increased radioactive isotope uptake. Drachman and Adams (1964) found increased uptake of radioactive arsenic over the temporal lobe in two cases.

The diagnosis of herpetic infections of the central nervous system by serology is complicated by the fact that crossreactions in complement-fixation tests have been reported between herpes and varicella-zoster viruses (Ross and Sharpe, 1965). Cerebral biopsy will be inevitable in certain cases to. exclude an abscess or tumour, and in these cases part of the specimen should be examined virologically.

Predilection for the temporal lobes, insula, cingulate gyrus;. and the orbital surface of the frontal lobes is evident from the numerous necropsy reports. Jellinger et al. (1964), in particular, gave full pathological details of an 18-year-old girl who. died as a result of virologically confirmed herpes simplex encephalitis. This case bears a striking resemblance to ours. In. addition to the major cerebral lesions both cases showed mild involvement of the spinal cord which correlated well with the clinical observation of progressive loss of tendon reflexes. Intranuclear inclusion bodies of the Cowdry type A are often: seen in association with herpes simplex encephalitis, but confirmed cases where no inclusion bodies were seen have been. described (Drachman and Adams, 1962 ; MacCallum et al. 1964 ; Pierce et al., 1964).

\section{Summary}

Acute necrotizing encephalitis due to herpes simplex virus is described in a 13-year-old girl. The virus was isolated from the brain at necropsy. The importance of recognizing the condition as a cause of raised intracranial pressure with focal neurological signs is discussed. The frequent finding of necrotic lesions in the temporal lobes is noted:

We should like to express our appreciation of the help given by many colleagues, both named and unnamed, in the investigation of this case.

\section{REFERENCES}

Adams, R. D., Berger, E. C., and van Bogaert, L. (1961). Encephalitides. Proceedings of a Symposium at Antwerp, 1959, p. 266. Elsevier. Amsterdam. 
Drachman, D. A., and Adams, R. D. (1962). Arch. Neurol. (Chic.), 7,

Haymaker, W. (1949). 7. Neuropalh. exp. Neurol., 8, 132.

Jellinger, K., Poetsch, F., and Seitelberger, F. (1964). Acta neuropath. (Berl.), 3, 278.

Leider, W., Magoffin, R. L., Lennette, E. H., and Leonards, L. N. R. (1965). New Engl. ‡. Med., 273, 341.
MacCallum, F. O., Potter, J. M., and Edwards, D. H. (1964). Lancet, 2, 332 .

Pierce, N. F. Portnoy, B., Leeds, N. E., Morrison, R. L., and Wehrle, P. F. (1964). Neurol. (Minneap.), 14, 708.

Ross, C. A. C., and Sharpe, J. H. S. (1965). Lancet, 2, 708.

Smith, M. G., Lennette, E. H., and Reames, H. R. (1941). Amer. F. Path., 17. 55.

\title{
Osteomalacia in Asian Immigrants During Pregnancy
}

\author{
D. J. C. FELTON,* M.B., M.R.C.o.g.; W. D. STONE, † B.M., M.R.C.P.
}

[With Special Plate]

Brit. med. F., 1966, 1, 1521-1522

Rickets and mild osteomalacia have been found in a number of Asian immigrants to the United Kingdom (Dunnigan et al., 1962). Pregnancy can precipitate florid osteomalacia in this group, but in women who speak little English it is not easy to distinguish significant symptoms from the muscular pains common in pregnancy.

\section{Case 1}

A Punjabi para-4 aged 29, resident in Birmingham for four years, complained of severe headache and limb pains during her fourth pregnancy in 1963. In January 1964 when 10 weeks pregnant she was admitted to hospital with vomiting and generalized aches and pains. A urinary infection was treated. When 18 weeks pregnant she complained of severe pains in the back, pelvis, and thighs, made worse by sitting or bending. Six weeks later difficulty in walking and muscular weakness were also present ; rest in hospital produced only slight improvement. When 35 weeks pregnant she was admitted because "she walks with great difficulty, almost in agony." Bony tenderness was widespread and the diagnosis of osteomalacia was suggested. Pseudo-fractures were seen in the right fourth and fifth ribs and in the left scapula (Special Plate, Fig. 1). The iliac crest was so soft that it was easily cut with a scalpel, but preparation of the biopsy was unsatisfactory. Treatment with calcium and vitamin $\mathrm{D}$ resulted in slow but steady improvement, and she was discharged free of pain two weeks after a normal labour and delivery of a healthy child weighing $7 \mathrm{lb} .11 \mathrm{oz}$. $(3,490 \mathrm{~g}$.). There was still some muscular weakness, but six weeks later she was walking normally. Four months later an $x$-ray examination showed that the fractures had healed.

\section{Case 2}

A Punjabi para-5 aged 37 had been in Birmingham for six years, and her last three pregnancies had been in this country. She was first seen in the antenatal clinic when 34 weeks pregnant. She had difficulty in walking, and had a waddling gait. She complained of pain in the back and pelvis and was tender over the lumbar spine. An $x$-ray film of the pelvis showed generalized demineralization. A diagnosis of osteomalacia was made and treatment begun with calcium and vitamin D. She was discharged after five weeks' treatment, free of pain and walking normally, 10 days after a normal labour and delivery of a healthy child weighing $6 \mathrm{lb} .7 \mathrm{oz}$. $(2,920 \mathrm{~g}$.) .

* Senior Registrar in Obstetrics, Dudley Road Hospital, Birmingham. Present appointment: Senior Registrar, United Birmingham Hospitals.

† Senior Registrar in Medicine, Dudley Road, Hospital, Birmingham.

\section{Case 3}

A Punjabi primigravida aged 21 had been in the United Kingdom for 10 months. When 35 weeks pregnant she was admitted as an emergency with pain in the back. There was pain and tenderness in both renal angles, but the diagnosis of pyelonephritis was rejected after two negative cultures of the urine. An $x$-ray film (Special Plate, Fig. 2) showed pseudo-fractures of both 11 th ribs, and it was realized that tenderness was localized to these points. There was no history of trauma and she had no cough. After one week's treatment with calcium and vitamin $\mathbf{D}$ pain was much improved. A bone biopsy two weeks later showed borderline osteomalacia. Labour and delivery were normal.

\section{Investigations}

For all three cases, levels of serum calcium, phosphate, and alkaline phosphatase, and the urinary calcium output, are shown in the Table. All patients had normal plasma proteins, blood urea, serum electrolytes, and stool-fat excretion. They were only mildly anaemic. Cases 2 and 3 showed a slight respiratory alkalosis, ascribed to hyperventilation in these anxious women. None had glycosuria, but Case 3 showed a mild generalized amino-aciduria, presumably secondary to the nutritional deficiencies (Harrison and Harrison, 1957).

\section{Discussion}

Rickets and osteomalacia are common in Northern India and Pakistan (Wilson, 1931 ; Taylor and Marshall Day, 1940), the main cause being widespread dietary deficiencies of vitamin $D$

\begin{tabular}{|c|c|c|c|c|c|c|c|c|}
\hline \multirow[b]{2}{*}{$\begin{array}{l}\text { Case } \\
\text { No. }\end{array}$} & \multicolumn{4}{|c|}{ Before Treatment } & \multicolumn{4}{|c|}{ After 4-5 Weeks' Treatment } \\
\hline & $\begin{array}{c}\text { Serum } \\
\text { Calcium } \\
\text { (mg./ } \\
100 \mathrm{ml} .)\end{array}$ & $\begin{array}{c}\text { Serum } \\
\text { Phos- } \\
\text { phate } \\
(\mathrm{mg} \cdot / \\
100 \mathrm{ml} .)\end{array}$ & $\begin{array}{c}\text { Serum } \\
\text { Alkaline } \\
\text { Phos- } \\
\text { phatase } \\
\text { (K-A. } \\
\text { Units) }\end{array}$ & $\begin{array}{l}\text { Urinary } \\
\text { Calcium } \\
\text { (mg./ } \\
24 \text { hr.) }\end{array}$ & $\begin{array}{l}\text { Serum } \\
\text { Calcium }\end{array}$ & $\begin{array}{l}\text { Serum } \\
\text { Phos- } \\
\text { phate }\end{array}$ & $\begin{array}{l}\text { Serum } \\
\text { Alkaline } \\
\text { Phos- } \\
\text { phatase }\end{array}$ & $\begin{array}{l}\text { Urinary } \\
\text { Calcium }\end{array}$ \\
\hline $\begin{array}{l}1 \\
2 \\
3\end{array}$ & $\begin{array}{l}8 \cdot 7 \\
8 \cdot 1 \\
9 \cdot 1\end{array}$ & $\begin{array}{l}2 \cdot 0 \\
3 \cdot 3 \\
2 \cdot 5\end{array}$ & $\begin{array}{c}171 \\
56 \\
24 \cdot 5\end{array}$ & $\begin{array}{l}77 \\
53 \\
77\end{array}$ & $\begin{array}{r}10 \cdot 1 \\
9 \cdot 6 \\
9 \cdot 4\end{array}$ & $\begin{array}{l}2 \cdot 7 \\
3 \cdot 7 \\
4.9\end{array}$ & $\begin{array}{l}30 \\
14 \cdot 7 \\
14 \cdot 7\end{array}$ & $\begin{array}{l}40 \\
69 \\
79\end{array}$ \\
\hline
\end{tabular}

Normal ranges: serum calcium, 9.3-10.4 mg./100 ml.; serum phosphate, 2.8$5.0 \mathrm{mg} . / 100 \mathrm{ml}$.; serum alkaline phosphatase, $4 \cdot 5-16 \mathrm{~K}-\mathrm{A}$. units; urinary calcium, 